\title{
Analysis of information disclosure for chilean case using multiple correspondence methodology
}

\author{
Análisis de revelación de la información para el caso chileno usando \\ la metodología de correspondencias múltiples
}

Berta Silva Palavecinos ${ }^{1}$

Hanns de la Fuente Mella ${ }^{1}$

Ricardo Campos Espinoza ${ }^{1}$

David Cademartori Rosso ${ }^{1}$

Recibido 15 de julio de 2014, aceptado 9 de septiembre de 2015

Received: July 15, 2014 Accepted: September 9, 2015

\begin{abstract}
Investors need reliable information for decision-making, so it is important to measure the quality of public information disclosed by quoted companies. This paper advances in the measurement of disclosed information using the multiple correspondence analysis methodology to reduce the number of traditionally used variables, resulting in three variables: i) disclosure of accounting policies and criteria, ii) disclosure of financial information and iii) disclosure of the board assessment. Using three these dimensions, we characterize and classify the analyzed companies according to their information disclosure.
\end{abstract}

Keywords: Information disclosure, determining dimensions, multiple correspondence analysis, corporate governance.

\section{RESUMEN}

Los inversionistas necesitan disponer de información confiable para la toma de decisiones, por ello es importante medir la calidad de la información revelada públicamente por las sociedades cotizadas. En este trabajo se avanza en la medición de la calidad de la información revelada usando la metodología de análisis de correspondencias múltiples, que para el caso analizado reduce el número de variables tradicionalmente utilizadas por la literatura a tres dimensiones: revelación de políticas y criterios contables, revelación de información financiera y revelación de la evaluación del directorio. Usando las dimensiones obtenidas se caracteriza y clasifica a las empresas analizadas en función de la revelación que muestra cada una de ellas.

Palabras clave: Revelación de información, dimensiones de revelación, análisis de correspondencias múltiples, gobierno corporativo.

\section{INTRODUCTION}

The pursuit of investment returns and the efficient management of resources are the main concerns of investors. However, in business administration, it is common to consider ownership and control separately, as the corresponding objectives of the administrators and investors may not necessarily be aligned. This lack of alignment may negatively affect information disclosure, leading to what is known as the agency problem in the Theory of the Firm [1].

\footnotetext{
1 Escuela de Comercio. Facultad de Ciencias Económicas y Administrativas. Pontificia Universidad Católica de Valparaíso. Av. Brasil 2830. Valparaíso, Chile.E-mail: bsilva@ucv.cl; ricardo.campos.e@ucv.cl; hanns.delafuente@ucv.cl; dcademar@ucv.cl
} 
The development of financial markets require that the information disclosed to the providers of capital meet certain quality and transparency conditions, such that investors can have confidence in their investments. Financial markets are transparent if there is truthful and equitable communication of all relevant information to investors.

Assessment of the quality of information provided to investors by securities issuers is based both on general frameworks endorsed by important international entities, and on the practices that result in crises and losses for investors (e.g., the cases of Enron and WorldCom in the USA, Parmalat in Italy and La Polar in Chile).

[2] Identifying key principles for securities markets regulation in 2003, which included the timely and complete diffusion of financial results and the disclosure of all pertinent information for investor decision-making. [3] Indicated in 2004 that all material questions relevant to the company should be revealed, including those concerning ownership and corporate governance. In 2010, [4] the conceptual framework of general purpose financial reporting was modified, optimizing it specifically for the use of investors and creditors.

The Chilean stock market displays a high concentration of ownership. The average percentage of ownership of the largest shareholders of the 40 securities from the Selective Stock Price Index of Chile (IPSA, by its initials in Spanish) is $41 \%$. In contrast, a random sample of 100 companies from the S\&P 500 has an average percent ownership of only $9 \%$ [5-7].

In Chile, the minimum information that should be disclosed by companies on the securities register is established by guidelines from the Superintendent of Securities and Insurance of Chile (SVS, by its initials in Spanish). These guidelines were developed in 1989, with changes in 2012 and 2013. The guidelines allow the board to take advantage of the minimum information disclosure requirements to exercise discretion in presenting results [8].

This motivates and provides an argument for the present paper, which reviews the most significant components of certain information disclosure indices proposed by various authors. Using multiple correspondence analysis, we determine the dimensions of information disclosure for companies listed on the Chilean stock exchange.

This paper is organized as follows. In section 2, we review the literature on information disclosure and the components considered in some information indicators constructed by various authors. In section 3, we formulate the research objectives and methodology. In section 4, we show the data analysis and results. Finally, in section 5, we present the conclusions.

\section{THEORETICAL BACKGROUND}

\section{Information needs of capital markets}

The demand for financial information and the need for its disclosure are caused by information asymmetry and agency conflicts between the administrators and investors, who do not participate in the management of the company [9]

Measuring information asymmetry is not an easy task. An indirect way of measuring it is to consider it as a function of the bid-ask spread, such that a larger spread implies greater information asymmetry [10] Companies with poor transparency and information disclosure practices will experience severe asymmetry [11].

[12] Note that the most efficient boards are those that disclose more information to the market, and then reduce the information asymmetry allowing appropriate choice of financing strategy

[13] Studied the disclosure of information in the future and concluded that the size of the company is the only factor that significantly influences all of the attributes of information (quantity, scope and quality).

\section{Information disclosure to the capital market}

Delivering more information to the capital market as part of good corporate governance is positively related to corporate growth and profitability [14]. The availability of information is a key factor in decisions related to assigning resources, and it greatly influences economic growth [15].

Disclosure is a theoretical concept that is very difficult to measure directly, and various authors have proposed 
proxy variables, including American Depositary Receipt (ADR) issuance, listing time on the stock exchange, the existence of certain regulations and company size. Furthermore, information disclosure is determined by internal mechanisms of corporate governance, so we consider authors who in some cases refer to good corporate governance indices and not only to information transparency and quality indices. The best way to protect shareholders and allow them to exercise their rights is thought to be to provide them with information of sufficient quality to assess company performance [16].

There is also a distinction between voluntary information disclosure and disclosure required by law or regulations [17]. Companies provide information through regulated financial reports, although there are also companies that voluntarily provide information on management forecasts [17-18]. Information disclosure is carried out by way of reports, and it is necessary to measure information quality with indicators.

\section{Dimensions in information disclosure}

Determining the dimensions that make up the information disclosure index is an important tool for assessing the information transparency of a company. Various authors have tried to determine how many dimensions a corporate governance quality measure should consider [19].

In constructing these measures, we are faced with difficulties in selecting the items (components) and determining their weighting [20]. A measure of corporate governance quality may be composed of both quantitative and qualitative components. For example, [21] constructed an index that includes both types of components, although it gives greater weight to quantitative measures.

From another perspective, we can distinguish between corporate governance quality measures constructed using open methodologies and those designed by autonomous entities (e.g., Standard \& Poor's, CLSA). In the latter case, the measurement may be criticized if it is calculated based on the request of a company and is consequently based on a biased sample [22].

Various authors have carried out measurements of information disclosure by considering different items or components. Some of the most important examples are the following: Company data [21,23], Information on forecasts [21, 23-25, 27], Information on company management $[21,23]$, Financial accounting information [21, 23- 25, 27], information on external auditors [24-25, 2728], Information on the board of directors [24-25, 27-28], Information on segments [24-25, 27, 29], Voluntary and mandatory annual (10-K form) and quarterly (Form 10-Q) information, required by regulatory entities, such as the Securities and Exchange Commission (SEC) [30].

\section{RESEARCH OBJECTIVES AND METHODOLOGY}

The purpose of this work is to propose a methodology for classifying the analyzed companies based on an information disclosure index (TI). The method should reduce the dimensions related to information delivery by the company, facilitate the understanding of information quality and transparency and fix the problem of low index variability identified in a previous study [31-32].

The new index should be based on the items proposed [25]. Furthermore, we will conduct positioning of the companies from the sample according to the received assessments.

This study has been conducted on a sample of 68 Chilean companies that were listed on the Chilean stock market for the 1999-2009 period. We used financial and non-financial information published by the SVS. The sample constitutes approximately $18 \%$ of the companies that are currently listed on the Santiago Stock Exchange, representing $69.2 \%$ of the market capitalization of the companies included in the IPSA and $48.4 \%$ of the entire Chilean market capitalization. Financial companies have been excluded, as these are entities regulated by the Superintendence of Banks and Financial Institutions (SBFI). As noted [33], these entities are usually subject to more control by regulators, who influence their information disclosure practices. The information source considered corresponds to annual reports, which are, in the opinion of some authors, a good approximation of the level of information disclosed by companies [13, 21, 34-35]. 
The 17 components used in this investigation to study the dimensions comprising the information disclosure (TI) are based on [25]. According to the taxonomy defined by [26] for transparency indices, the nature of the indicator used in the document corresponds to the category called "discretionary disclosure", and the object being studied is the degree of discretion with which administrators deliver information.

Given the qualitative nature of the variables expressed in the ordinal scale (5-point Likert scale), it is appropriate to use multiple correspondence analysis [36]. For this study, we used multidimensional analysis, which explains the majority of TI variance and provides the best interpretation of the phenomenon. This methodology allows us to reduce the dimensions of the TI to characterize and classify the sample companies in terms of the dimensions.

\section{DATA ANALYSIS AND RESULTS}

\section{Data analysis}

The gathered data represent general information about the companies, information contained in the notes of the company financial statements, information about external auditors and information about the directors (Board of Directors).
Based on descriptive analysis of the sample, we find that the items with the lowest scores on a scale of 1 to 5 are those that relate to the following factors: the disclosure of information on non-auditor professional fees, intracompany and intercompany industry regulations, interim reviews of the accounting system, principal financial and non-financial features, the assignment of independent professional consultants, the company secretarial system and the involvement and relationships with external auditors (see Table 1).

The highest-scoring items include those representing the concentration of ownership, the fines and penalties, the directors' remuneration and the assessment of the company's position. This can be observed by looking at the median values of the variables in Table 1.

\section{Results}

The aim of this study was to find links between the 17 components and to identify the positions of the sample companies. According to relationships identified between the components and the analyzed literature, and based on the discrimination measures of the components, we have decided to use three dimensions. Table 2 shows the eigenvalues for each of the dimensions selected for analysis, presenting for each of them the variance measurement explained by each dimension. The magnitude of

Table 1. Variables used in developing the index and their main values.

\begin{tabular}{|c|c|c|c|c|c|}
\hline Variable & mín. & $\max$. & scope & trend & median \\
\hline a. Disclosure of external audit & 1 & 5 & 4 & 2 & 2 \\
\hline b. Disclosure of notes on deferred tax & 1 & 5 & 4 & 5 & 5 \\
\hline c. Disclosure of non-auditing professional fees & 1 & 5 & 4 & 1 & 1 \\
\hline d. Disclosure of accounting policies and criteria & 1 & 5 & 4 & 4 & 4 \\
\hline e. Disclosure of interim reviews of the accounting system & 1 & 2 & 1 & 1 & 1 \\
\hline f. Disclosures in notes on industry regulation & 1 & 4 & 3 & 1 & 1 \\
\hline g. Disclosure of financial and non-financial forecasts & 1 & 3 & 2 & 1 & 1 \\
\hline h. Availability of financial information sources & 1 & 5 & 4 & 5 & 5 \\
\hline i. Disclosure of ownership concentration & 1 & 5 & 4 & 5 & 5 \\
\hline j. Disclosure of the assignment of consultants and others & 1 & 2 & 1 & 1 & 1 \\
\hline k. Disclosure of financial information by segments & 1 & 5 & 4 & 1 & 1 \\
\hline 1. Disclosure of fines and penalties & 1 & 5 & 4 & 5 & 5 \\
\hline m. Disclosure of involvement of external auditors & 1 & 2 & 1 & 1 & 1 \\
\hline n. Disclosure of relationships with external auditors & 1 & 3 & 2 & 1 & 1 \\
\hline o. Disclosure of the directors' remuneration policy & 1 & 5 & 4 & 1 & 1 \\
\hline p. Disclosure of the directors' remuneration amounts & 1 & 5 & 4 & 5 & 5 \\
\hline q. Disclosure of the directors' assessment & 1 & 5 & 4 & 5 & 5 \\
\hline
\end{tabular}


this variance determines the degree of importance of this dimension in the global solution.

In Table 2, we observe that the three dimensions have nearly the same importance. Similar amounts of variance are explained by each of them ${ }^{2}$.

Based on our analysis methodology, we have generated a graph that facilitates the interpretation of the results obtained for each dimension (Figure 1).

In the graph of the discrimination measures (see Figure 1), we can observe that the variables $d, b, h$, $l$ and $a$ are components of the TI, all grouped in one dimension (dimension 1). Components $m, n$ and $k$ are associated with another dimension (dimension 2). A new group of variables associated with a third dimension (dimension 3 ) includes variables $q$ and $g$, although the variables $m$ and $n$ also show a strong association with this dimension. Of the remaining variables, $c, e, f, i, j p$ and $o$ have similar discrimination measures, which makes it difficult to assign them to any dimension (Table 3).

Table 2. Dimension components and eigenvalues of the TI.

\begin{tabular}{|c|c|c|}
\hline Dimension & Cronbach'sAlpha & Total (Eigenvalue) \\
\hline 1 & 0,938 & 13,715 \\
\hline 2 & 0,925 & 11,630 \\
\hline 3 & 0,916 & 10,513 \\
\hline
\end{tabular}

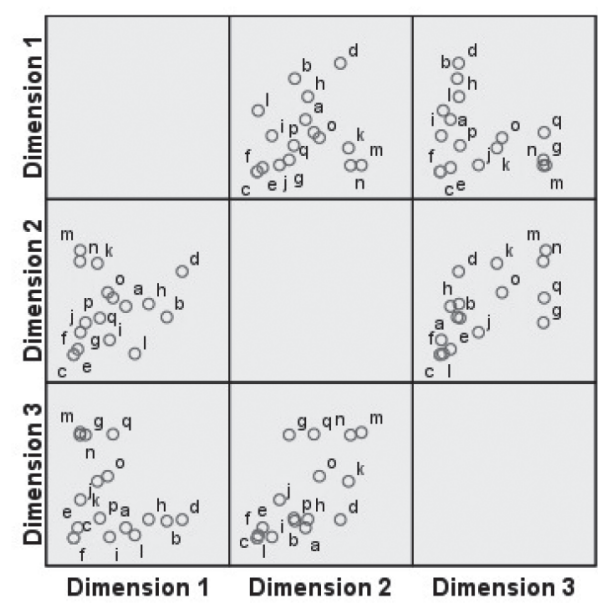

Figure 1. Discrimination measures.

\footnotetext{
2 The reliability of the scale is validated by considering the good values of Cronbach's alpha [36].
}

Dimension 1 has a scope related to the following factors: disclosure of accounting policies and criteria in the notes of the financial statements, the availability of financial information sources, the main aspects of external audit and fines and fees paid to or by the company. Dimension 2 is mainly related to the disclosure of financial information by segments. Dimension 3 includes the effect of disclosure of the Board of Directors' assessment on the position of the company and forecasts.

Regarding the second analysis, based on the results presented in Figure 2, we observe the

Table 3. Discrimination measures of the TI components.

\begin{tabular}{|c|c|c|c|}
\hline TI Components & \multicolumn{3}{|c|}{ Dimension } \\
\hline & 1 & 2 & 3 \\
\hline A & 0,244 & 0,152 & 0,033 \\
\hline B & 0,436 & 0,118 & 0,054 \\
\hline C & 0,001 & 0,002 & 0,001 \\
\hline D & 0,508 & 0,261 & 0,058 \\
\hline E & 0,020 & 0,018 & 0,033 \\
\hline F & 0,000 & 0,000 & 0,001 \\
\hline G & 0,056 & 0,101 & 0,322 \\
\hline H & 0,352 & 0,159 & 0,059 \\
\hline I & 0,169 & 0,047 & 0,004 \\
\hline J & 0,032 & 0,071 & 0,120 \\
\hline K & 0,111 & 0,286 & 0,177 \\
\hline L & 0,287 & 0,004 & 0,010 \\
\hline M & 0,031 & 0,326 & 0,330 \\
\hline N & 0,030 & 0,292 & 0,322 \\
\hline O & 0,159 & 0,195 & 0,193 \\
\hline P & 0,123 & 0,116 & 0,062 \\
\hline Q & 0,184 & 0,178 & 0,324 \\
\hline
\end{tabular}

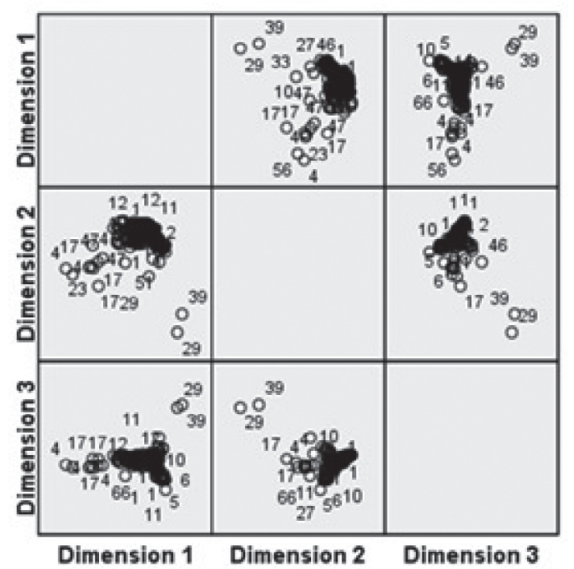

Figure 2. Scores of objects labeled according to company. 
representative measures of the variance assigned to each company within each variable in the context of a given dimension. As in the previous case, scores tend toward zero at equilibrium positions, and as the value increases, it becomes more likely that the object will be represented by the conducted analysis. Upon interpretation of the results, we can establish which companies would be part of the same homogenous group according to the selected dimension. For example, for dimension 1, these would be companies 4 and 17. For dimension 2, companies 29 and 39 would be grouped together. For dimension 3, companies 6 and 10 go together. By observing the company discrimination measures, it is possible to establish with greater accuracy and detail the most revealing dimensions in each of the companies in the sample (see Table 4).

Table 4. Factors of information disclosure listed by company.

\begin{tabular}{|c|c|c|c|c|c|c|c|}
\hline Company ID & D1 & D2 & D3 & Company ID & D1 & D2 & D3 \\
\hline 1 & 0.465 & 0.315 & 0.27 & 35 & 0.945 & 0.951 & 0.941 \\
\hline 2 & 0.475 & 0.471 & 0.442 & 36 & 0.44 & 0.34 & 0.612 \\
\hline 3 & 0.345 & 0.195 & 0.234 & 37 & 0.662 & 0.442 & 0.7 \\
\hline 4 & 1.624 & 0.942 & 0.449 & 38 & 0.417 & 0.48 & 0.453 \\
\hline 5 & 0.626 & 0.314 & 0.83 & 39 & 0.685 & 1.758 & 1.678 \\
\hline 6 & 0.775 & 0.483 & 0.918 & 40 & 0.354 & 0.852 & 0.72 \\
\hline 7 & 0.584 & 0.415 & 0.493 & 41 & 1.044 & 0.916 & 1.08 \\
\hline 8 & 0.309 & 0.295 & 0.211 & 42 & 0.851 & 0.779 & 1.014 \\
\hline 9 & 0.324 & 0.456 & 0.171 & 43 & 0.257 & 0.165 & 0.277 \\
\hline 10 & 0.595 & 0.462 & 0.603 & 44 & 0.605 & 0.83 & 0.535 \\
\hline 11 & 0.762 & 0.919 & 0.953 & 45 & 0.368 & 0.22 & 0.174 \\
\hline 12 & 0.752 & 0.38 & 0.14 & 46 & 0.435 & 0.566 & 0.64 \\
\hline 13 & 0.719 & 0.515 & 0.408 & 47 & 1.323 & 0.614 & 0.439 \\
\hline 14 & 0.239 & 0.177 & 0.626 & 48 & 2.048 & 0.786 & 0.643 \\
\hline 15 & 0.452 & 0.27 & 0.188 & 49 & 0.881 & 0.444 & 0.309 \\
\hline 16 & 0.451 & 0.504 & 0.191 & 50 & 0.479 & 0.112 & 0.281 \\
\hline 17 & 1.771 & 1.355 & 0.406 & 51 & 0.365 & 0.573 & 0.651 \\
\hline 18 & 0.14 & 0.346 & 0.209 & 52 & 0.556 & 0.146 & 0.349 \\
\hline 19 & 0.713 & 0.485 & 0.584 & 53 & 1.405 & 0.535 & 0.495 \\
\hline 20 & 0.5 & 0.486 & 0.175 & 54 & 0.742 & 0.346 & 0.149 \\
\hline 21 & 0.42 & 0.289 & 0.153 & 55 & 1.067 & 0.811 & 0.597 \\
\hline 22 & 0.565 & 0.345 & 0.415 & 56 & 1.225 & 1.041 & 0.32 \\
\hline 23 & 0.991 & 0.748 & 0.66 & 57 & 0.969 & 0.762 & 0.552 \\
\hline 24 & 0.498 & 0.605 & 0.457 & 58 & 0.749 & 0.482 & 0.385 \\
\hline 25 & 0.629 & 0.845 & 0.734 & 59 & 0.441 & 0.402 & 0.303 \\
\hline 26 & 0.448 & 0.423 & 0.24 & 60 & 0.493 & 0.678 & 0.653 \\
\hline 27 & 0.647 & 0.44 & 0.766 & 61 & 0.679 & 0.6 & 0.552 \\
\hline 28 & 0.635 & 0.752 & 0.811 & 62 & 0.84 & 0.585 & 0.6 \\
\hline 29 & 0.839 & 1.414 & 1.095 & 63 & 0.776 & 0.533 & 0.413 \\
\hline 30 & 0.338 & 0.26 & 0.197 & 64 & 0.39 & 0.235 & 0.288 \\
\hline 31 & 0.376 & 0.574 & 0.573 & 65 & 0.589 & 0.455 & 0.712 \\
\hline 32 & 0.139 & 0.481 & 0.425 & 66 & 0.845 & 0.659 & 0.86 \\
\hline 33 & 0.457 & 0.906 & 0.369 & 67 & 0.502 & 0.373 & 0.896 \\
\hline 34 & 0.285 & 0.175 & 0.216 & 68 & 0.444 & 0.333 & 0.258 \\
\hline
\end{tabular}


Based on the factors presented in Table 4, we can state that $53 \%$ of the companies in the sample mainly disclose the following information: information related to accounting policies and criteria in the notes of the financial statements, information about the availability of financial information sources, information about the main aspects of external audits and information about the fines or fees paid to or by the company. In total, $22 \%$ of the sample companies disclose information related to financial information by segments, and $25 \%$ of the sample companies disclose information about the director's assessment of the position of the company and the director's forecasts for important financial and non-financial indicators.

Moreover, with the coefficients achieved for each dimension, it is possible to rank or group the companies according to the degree of information disclosure in each dimension. For example, in
Figure 3, the 68 samples are grouped into quartiles according to the coefficients from dimension 1 , and we can also observe the degree of contribution of each company in explaining the total disclosure of information in this dimension. This figure shows that there is a greater dispersion in the coefficients of the companies in the first quartile (ranging from Telsur to Marinsa, with coefficients of 2.05 to 0.78 , respectively) than in those of the other three quartiles. The maximum distance in the first quartile is 1.27 , and in the other quartiles, the distances are significantly smaller $(0.19,0.14$ and 0.29$)$.

\section{CONCLUSIONS}

Given that the information disclosure indexes obtained in previous studies did not allow for adequate distinctions between the quality of disclosed information from different companies, low variability was observed as a result of the average score obtained

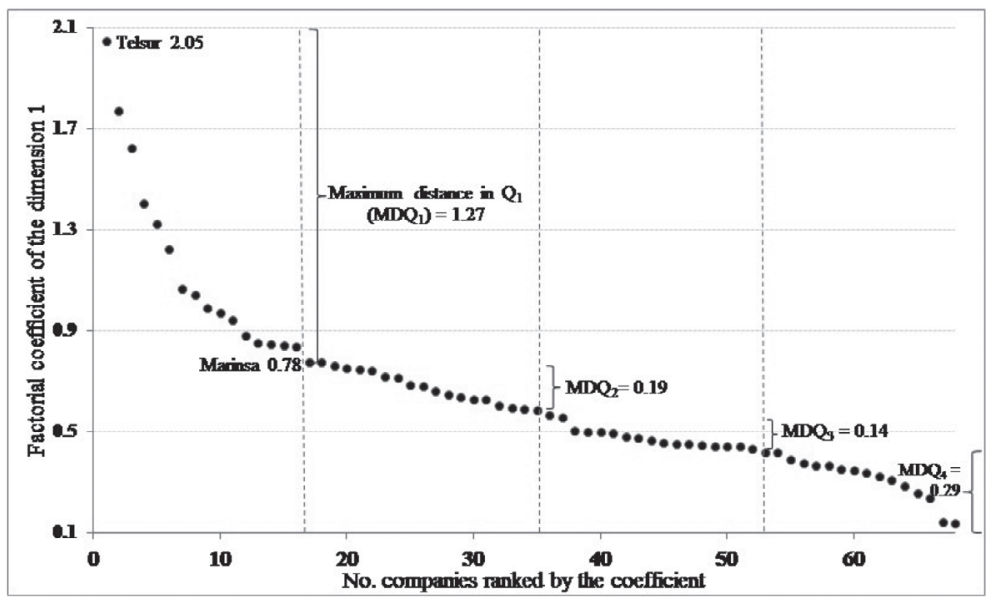

Figure 3. Factor coefficients for Dimension 1 (D1) of each company.

Note: Companies ordered (total of 68) according to the value of the coefficient (in abscissa) and grouped in quartiles (ordered by exhibit). For each quartile, the companies are ordered from highest to lowest value of the coefficient, and we can observe the maximum distance in each quartile (MDQ1, MDQ2, MDQ3 and MDQ4):

1st quartile (Q1): Telsur, CEM, Cintac, Telefonica Mundo, Pesquera Itata, Chilectra, CGE Transmisiones, Eperva, Copec, Zofri, Gener, Soc. Punta del Cobre, Entel, CMPC, Melón, Duncan Fox, Marinsa.

2nd quartile (Q2): Enersis, Endesa, Invers. Tricahue, Masisa, Cervezas CCU, Soquicom, Cementos BioBio, CTC, Madeco, Gasco, Esval, Pilmaiquen, Coca Cola Polar, Pehuenche, Sud Americana de Vapores, Emelari, Enaex.

3rd quartile (Q3): Viña San Pedro, Concha y Toro, Eliqsa, Cholguan, Cia. Chilena de Tabacos, Coloso, Indiver, Elecda, Banmedica, Aguas Andinas, Edelnor, Calichera, Campos, Sipsa, Sta. Emiliana, Inforsa, Iansa.

4th quartile (Q4): Invercap, Besalco, CTI, Colbun, Minera Valparaíso, Ventanas, Elecmetal, Cristalerias de Chile, Almendral, Antarchile, Soquimich, Soc. de Tattersal, Edelmag, Cía. Chilena de Fósforos, CAP, Parque Arauco, Pasur. 
in the different items. This study was enhanced by incorporating the multiple correspondence analysis methodology. The previous TI indicator did not allow us to efficiently differentiate between companies because, for example, it included non-discriminating variables $(c, f)$.

This study has detected three significant dimensions of disclosed information: (i) accounting policies and criteria, (ii) strategic issues and (iii) the definition and assessment of corporate policies. Each of the three dimensions discriminates on its own, thus facilitating the degree of transparency of the companies when offering public information, allowing for an improvement in the analysis of information quality.

All the companies meet the minimum information required for disclosure to their shareholders and to the market, as established by General Rule 30 [37-39]. Some companies voluntarily pass on more information. For example, some provide similar information for the three areas (dimensions), while others only do so for certain dimensions. The last group of companies, comprising those that provide poor information, displays greater variability in the dimension coefficients. The first group, in contrast, has relatively homogenous disclosure.

In the Chilean stock exchange, listed companies reveal information as necessary to comply with the rules, rather than reporting information voluntarily.

The methodology used allows us to analyze the disclosure behavior of the set of studied companies. For each of the companies, we can calculate a new index, emphasizing the positioning of each entity and its characterization. We can also perform extensive calculations of the indexes of other Latin American markets.

\section{REFERENCES}

[1] M. Jensen and W. Meckling. "Theory of the Firm: Managerial Behavior, Agency Costs and Ownership Structure". Journal of Financial Economics. Vol. 3, Issue 4, pp. 305-360. 1976.

[2] International Organization of Securities Commissions (IOSCO). "Metodología para evaluar la implantación de los objetivos y principios de la OICV para la regulación de los mercados de valores". Date of visit: May 25, 2011. URL: https://www.iosco. org/library/pubdocs/pdf/IOSCOPD155Spanish.pdf

[3] Organization for Economic Co-operation and Development (OECD). "Principios de Gobierno Corporativo de la OCDE". Date of visit: July 20, 2011. URL: http://www. oecd.org/dataoecd/47/25/37191543.pdf

[4] International Accounting Standards Board (IASB). "The Conceptual Framework for Financial Reporting", pp. 1-66. Date of visit: July 15, 2010. URL: http://www. aasb.gov .au/admin/file/content102/c3/ Oct_2010_AP_9.3_Conceptual_Framework_ Financial_Reporting_2010.pdf

[5] A. Rubin. "Ownership Level, Ownership Concentration and Liquidity". Journal of Financial Markets. Vol. 10, Issue 3, pp. 219248. 2007.

[6] F. Coloma. "Desafíos de la Regulación de Gobiernos Corporativos en Chile". Jornada de Gobierno Corporativo. Santiago, Chile, 18 de Octubre de 2010.

[7] M. Rapaport and H.H. Sheng. "Ownership Structure and Firm Value in Brazil". Revista Latinoamericana de Administración. Vol. 45, pp. 76-95. 2010.

[8] J. Zhou and G. Lobo. "Disclosure Quality and Earnings Management". Asia-Pacific Journal of Accounting and Economics. Vol. 8, Issue 1, pp. 1-20. 2001.

[9] P. Healy and K. Palepu. "Information Asymmetry, Corporate Disclosure, and the Capital Markets: A review of the Empirical Disclosure Literature". Journal of Accounting and Economics. Vol. 31, Issue 1-3, pp. 405440. 2001.

[10] Y. Amihud and H. Mendelson. "Effects of Beta, Bid-Ask Spread, Residual Risk, and Size on Stock Returns". The Journal of Finance. Vol. 44, Issue 2, pp. 479-486. 1989.

[11] W. P. Chen, H. Chung, C. Lee and W. L.Liao. "Corporate Governance and Equity Liquidity: Analysis of S\&P Transparency and Disclosure Rankings". Corporate Governance. Vol. 15, Issue 4, pp. 644-660. 2007.

[12] K. Kanagaretnam, G. Lobo and D. Whalen. "Does Good Corporate Governance reduce 
Information Asymmetry around Quarterly Earnings Announcements?. Journal of Accounting and Public Policy. Vol. 26, Issue 4, pp. 497-522. 2007.

[13] F. Bravo, Ma. C. Abad and M. Trombetta. "Disclosure Theories and Disclosure Measures". Revista Española de Financiación y Contabilidad. Vol. 39, Issue 147, pp. 393415. 2010.

[14] I. Khurana, R. Pereira and X. Martin. "Firm Growth and Disclosure: An Empirical Analysis". Journal of Financial and Quantitative Analysis. Vol. 41, Issue 2, pp. 357-380. 2006.

[15] R. Bushman, J. Piotroski and A. Smith. "What Determines Corporate Transparency?". Journal of Accounting Research. Vol. 42, Issue 2, pp. 207-252. 2004

[16] A. Cuervo. "Corporate Governance Mechanisms: plea for less code of good governance and more market control". Corporate Governance. Vol. 10, Issue 2, pp. 84-93. 2002.

[17] C. Bagnoli and G. M. Mantovani. "Voluntary Disclosure Strategies and the Cost of Capital of Italian blue chips". Journal of Business, Economics \& Finance. Vol. 1, Issue 4, pp. 49-94. 2012.

[18] P. Healy and K. Palepu. "Information Asymmetry, Corporate Disclosure and the Capital Market: A review of empirical disclosure literature". Journal of Accounting and Economics. Vol. 31, Issue 1-3. 2001.

[19] A. Dey. "Corporate Governance and Agency Conflicts". Journal of Accounting Research. Vol. 46, Issue 5, pp. 1143-1181. 2008.

[20] E. García-Meca and J.P. Martínez. "Divulgación Voluntaria de Información Empresarial: índices de revelación. Partida Doble. Vol. 157, pp. 66-77. 2004.

[21] C. Botosan. "Disclosure Level and the Cost of Equity Capital". The Accounting Review. Vol. 72, Issue 3, pp. 323-349. 1997.

[22] C. Cheng, M. Courtenay and C. Krishnamurti. "The Impact of Increased Voluntary Disclosure on Market Information Asymmetry, Informed and Uninformed Trading". Journal of Contemporary Accounting \& Economics. Vol. 2, Issue 1, pp. 33-72. 2006.

[23] L.L. Eng, K.F. Hong and Y.K. Ho. "The Relation between Financial Statement
Disclosures and the Cost of Equity Capital of Singapore Firms". Accounting Research Journal. Vol. 14, Issue 1, pp. 35-48. 2001.

[24] M. Aksu and A. Kosedag. "Transparency and Disclosure Scores and their Determinants in the Istanbul Stock Exchange". Corporate Governance. Vol. 14, Issue 4, pp. 277-296. 2006.

[25] H.M. Haat, S. Mahenthiran, A.R. Rahman and A.N. Hamid. "Agency Costs as a Factor in the Suspension of Companies from the Kuala Lumpur Stock Exchange". Journal of Contemporary Accounting and Economics. Vol. 2, Issue 1, pp. 99-121. 2006.

[26] R. Verrecchia. "Essais on disclosure". Journal of Accounting \& Economics. Vol. 32, pp. 97180. 2001.

[27] M. Hassan, R. Abdul and S. Mahenthiran. "Corporate Governance, Transparency and Performance of Malaysian Companies". Managerial Auditing Journal. Vol. 23, Issue 8, pp. 744-778. 2008.

[28] U. Garay and M. Gónzalez. "Corporate Governance and Firm Value: The Case of Venezuela". Corporate Governance. Vol. 16, Issue 3, pp. 194-209. 2008.

[29] M.K. Hassan. "A Disclosure Index to Measure the Extent of Corporate Governance Reporting by UAE listed Corporations". Journal of Financial Reporting \& Accounting and Business Research. Vol. 10, Issue 1, pp. 4-33. 2012.

[30] C. Botosan and M. Plumlee. "A Reexamination of Disclosure Level and the Expected Cost of Equity Capital". Journal of Accounting Research. Vol. 40, Issue 1, pp. 21-40. 2002.

[31] V.Pizarro, S. Mahenthiran, D. Cademartori and R. Curci. "The Chilean Corporate Governance System: The Effect of Non-Bank Financial Intermediaries and Auditors on Earnings Quality and Disclosure Levels". Included a full paper in the Proceedings of the 2007 Journal of Contemporary Accounting and Economics (JCAE), 2nd JCAE symposium, pp. 1-26, Penang, Malaysia. 2007.

[32] B. Silva, D. Azúa, P. Díaz and V. Pizarro "The influence of institutional investors on the transparency of the Chilean capital market". Academia, Revista Latinoamericana de Administración. No 40, pp. 54-67. 2008. 
[33] D.L. Rodríguez, I. Gallego and S.I. García. "Determinants of Voluntary Disclosure Strategic Internet: a study of Spanish listed companies". Revista Europea de Dirección y Economía de la Empresa. Vol. 19, Issue 1, pp. 9-26. 2010.

[34] L.L. Eng and Y.T. Mak. "Corporate Governance and Voluntary Disclosure". Journal of Accounting and Public Policy. Vol. 22, Issue 4, pp. 325-345. 2003.

[35] N. Padia. "Disclosure of non Financial Information on Strategy in South African Annual Reports". African Journal of Business. Vol. 6, Issue 46, pp. 11472-11479. 2012.

[36] J.F. Hair, R.E. Anderson, R.L. Tatham, y W.C. Black. "Análisis Multivariante". Pearson Prentice Hall. Quinta Edición, pp. 571-592. Madrid, España. 1999. ISBN: 9788483220351.

[37] Superintendencia de Valores y Seguros (SVS). Norma de Carácter General 30.
Establece normas de inscripción de emisores y valores de oferta pública en el Registro de Valores, su difusión, colocación y obligaciones de información consiguientes, pp. 1-179. Date of visit: November 11, 2010. URL: http://www.svs.cl/normativa/ ncg_30_1989.pdf

[38] Superintendencia de Valores y Seguros (SVS) Norma de Carácter General 332. Modifica Normas de Carácter General № 30 de 1989 y No 118 de 2001 en los términos que indica, pp 1-7. Date of visit: May 25, 2012. URL: http://www.svs.cl/normativa/ ncg_332_2012.pdf

[39] Superintendencia de Valores y Seguros (SVS). Norma de Carácter General 346. Sustituye Secciones I, II y III y modifica secciones IV y V de Norma de Carácter General No 30, pp 1-72. Date of visit: August 5, 2010. URL: http://www.svs.cl/ normativa/ncg_346_2013.pdf 